Volume 16, No. 2, Juli 2019

Page: 809- 812

\title{
KUALITAS FISIK RUMAH DENGAN KEJADIAN PNEUMONIA PADA BALITA
}

\author{
Tri Nindia, Imam Santoso, Juanda \\ Poltekkes Kemenkes Banjarmasin Jurusan Kesehatan Lingkungan \\ Jl.H. Mistar Cokrokusumo No.1A Banjarbaru Kalimantan Selatan 70714 \\ Email : tri.nindyaa@gmail.com
}

\begin{abstract}
Abstrack : Physical Quality Density Of Houses With The Incedents Of Pneumonia In Children Under Five. Toddler pneumonia is an acute respiratory tract infection that is inflammation or irritation in one or both lungs, caused by infection. An illness is said to be acute if it has lasted \pm 14 days. The purpose of this study was to determine the relationship of physical quality of houses (lighting, temperature, and humidity) and occupancy density with the incidence of pneumonia in children under five in Kecamatan Astambul, Kabupaten Banjar. Analytical research design with approach retrospective (case control study) in case comparison: control 1: 1. The sample of cases in this study were all houses of pneumonia patients 25 houses in the Astambul Health Center area in November 2018 - January 2019. Data analysis used chi-square test.The results of the research statistic showed that the lighting conditions ( $p 0.321>\alpha 0.05$ ) had no relationship, the temperature conditions ( $p$ $0.244>\alpha 0.05)$ had no relationship, and the condition of humidity ( $p 1.00>\alpha 0.05)$ have no relationship with the incidence of pneumonia in infants.It is expected that counseling from Astambul public health center to society so they can increase knowledge and awareness about the requirements of a healthy home and pay attention to the health of their home environment.
\end{abstract}

Keywords : Physical Quality of Houses; Toddler Pneumonia

\begin{abstract}
Abstrak: Kualitas Fisik Rumah Dengan Kejadian Pneumonia Pada Balita. Pneumonia balita merupakan suatu penyakit infeksi saluran pernafasan akut, yaitu peradangan atau iritasi pada salah satu atau kedua paru, yang disebabkan oleh infeksi. Suatu penyakit dikatakan akut jika telah berlangsung selama \pm 14 hari. Tujuan penelitian ini untuk mengetahui hubungan kualitas fisik rumah (pencahayaan,suhu,dankelembaban) dan kepadatan hunian dengan kejadian pneumonia pada balita di Kecamatan Astambul Kabupaten Banjar. Desain penelitian analitik dengan pendekatan retrospektif ( case control study ) pada perbandingan kasus:kontrol 1:1. Sampel kasus dalam penelitian ini adalah semua rumah penderita pneumonia 25 rumah di Wilayah Puskesmas Astambul pada bulan November 2018 - Januari 2019.Analisis data menggunakan uji chi-square.Hasil uji statistik penelitian menunjukkan kondisi pencahayaan $(p 0,321>\alpha 0,05)$ tidak memiliki hubungan, kondisi suhu ( $p$ 0,244>a 0,05) tidak memiliki hubungan, dan kondisi kelembaban $(p 1,00>\alpha 0,05)$ tidak memiliki hubungan dengan kejadian pneumonia pada balita.Diharapkan dengan penyuluhan dari Puskesmas Astambul masyarakat mampu meningkatkan pengetahuan dan kesadaran tentang persyaratan rumah sehat serta memperhatikan kesehatan lingkungan rumahnya.
\end{abstract}

Kata Kunci : Kualitas Fisik Rumah; Pneumonia Balita

\section{PENDAHULUAN}

Rumah adalah bangunan tempat berlindung dan beristirahat serta sebagai sarana pembinaan keluarga yang menumbuhkan kehidupan sehat secara fisik, mental dan sosial, sehingga seluruh anggota keluarga dapat bekerja secara produktif. Oleh karena itu keberadaan perumahan yang sehat, aman, serasi, teratur sangat diperlukan agar fungsi dan kegunaan rumah dapat terpenuhi dengan baik[1]. Sanitasi rumah dan lingkungan erat kaitannya dengan angka kejadian penyakit menular, terutama ISPA (pneumonia atau bukan pneumonia) ${ }^{[2] .}$ 
Pneumonia merupakan penyakit mematikan nomor satu di dunia dengan prevelensi 44\%. Di Indonesia, pneumonia anak bawah lima tahun merupakan penyebab kematian nomor dua setelah diare dengan proporsi 15,5\%. Pneumonia merupakan penyakit yang disebabkan oleh virus dan bakteri yang di pengaruhi oleh pencemar fisik dan kimia[3].

Penyebaran penyakit pneumonia tersebar di 23 puskesmas di tahun 20132016 dan bertambah menjadi 24 puskesmas pada tahun 2017[4]. Berdasarkan data yang diperoleh dari Dinas Kesehatan Kabupaten Banjar tahun 2017, terdapat lima puskesmas dengan rata-rata 3 tahun tertinggi sejak 2015 sampai 2017 yaitu puskesmas Martapura 2 (7,3\%), Astambul (5,7\%), Gambut (4,6\%), Martapura $1(4,3 \%)$ dan Tatah Makmur $(2,8 \%)^{[4]}$. Beradasarkan data diatas diperoleh puskesmas dengan kasus pneumonia pada balita tertinggi yaitu di wilayah kerja Puskesmas Martapura 2, tetapi pada wilayah kerja Astambul memiliki kecendrungan kurva yang naik, sedangkan pada wilayah kerja Puskesmas Martapura 2 memiliki kecendrungan kurva yang turun. Wilayah kerja Puskesmas Astambul menempati posisi tertinggi kedua di Kabupaten Banjar, padahal wilayah kerja Puskesmas Astambul lebih kecil dibandingkan dengan wilayah kerja Puskesmas Martapura 2. Di wilayah kerja Puskesmas Martapura 2 lebih kompleksitas dibandingkan dengan wilayah kerja Puskesmas Astambul, dengan kompleksitas letak rumah masyarakat yang tidak terlalu rapat dan kepadatan hunian yang tidak terlalu rapat di wilayah kerja Puskesmas Astambul seharusnya tidak menempati posisi tertinggi kedua. Berdasarkan latar belakang masalah maka rumusan masalah penelitian ini adalah apakah ada hubungan antara kualitas fisik rumah dan kepadatan hunian dengan kejadian pneumonia pada balita di Kecamatan Astambul Kabupaten Banjar?

\section{METODE PENELITIAN}

Jenis penelitian ini bersifat analitik, desain penelitian yang digunakan yaitu pendekatan retrospektif (case control) adalah penelitian yang dilakukan dengan cara membandingkan kelompok kasus dan kelompok kontrol, untuk mengetahui proporsi kejadian berdasarkan riwayat ada tidaknya paparan dengan melihat kebelakang dari suatu kejadian yang berhubungan dengan kejadian kesakitan yang diteliti. Penelitian dilaksanakan sejak pembuatan proposal pada bulan Oktober 2018 sampai laporan hasil penelitian pada bulan Mei 2019.populasi dalam penelitian adalah semua keluarga yang memiliki balita Pneumonia yang terdaftar pada catatan register Puskesmas Astambul dan bertempat tinggal di Kecamatan Astambul selama tiga bulan terakhir (November, Desember, dan Januari). Sampel diambil dengan menggunakan teknik purposive sampling, yaitu dengan memilih sampel berdasarkan kriteria tertentu yang telah ditetapkan oleh peneliti. Sampel dalam penelitian ini sebanyak 50 responden.

\section{HASIL DAN PEMBAHASAN}

Jumlah responden dengan jenis kelamin laki-laki lebih banyak (72\%) dibandingkan perempuan (28\%), dan responden rata-rata berumur 2,2 tahun[5].

Tabel 1. Distribusi Frekuensi Responden Menurut Pencahayaan Rumah Dengan Kejadian Pneumonia Pada Balita

\begin{tabular}{|c|c|c|c|c|c|c|}
\hline \multirow{3}{*}{ No } & \multirow{3}{*}{ Pencahayaan } & \multicolumn{4}{|c|}{ Kejadian Pneumonia } & \multirow{3}{*}{ Jumlah } \\
\hline & & \multicolumn{2}{|c|}{ Kasus } & \multicolumn{2}{|c|}{ Kontrol } & \\
\hline & & $\mathrm{n}$ & $\%$ & $\mathrm{n}$ & $\%$ & \\
\hline 1. & Tidak memenuhi syarat & 21 & 84 & 17 & 68 & 38 \\
\hline 2. & Memenuhi syarat & 4 & 16 & 8 & 32 & 12 \\
\hline & Total & 25 & 100 & 25 & 100 & 50 \\
\hline \multicolumn{2}{|c|}{$p=0,321>\alpha=0,05$} & & & & & \\
\hline
\end{tabular}


Hasil analisis data dengan menggunakan uji chi-square diperoleh nilai $p$-value sebesar $0,321>\alpha(0,05)$ maka $\mathrm{H}_{\mathrm{o}}$ diterima sehingga dapat dikatakan bahwa tidak ada hubumgan antara pencahayaan dengan kejadian pneumonia pada balita di Kecamatan Astambul Kabupaten Banjar. Dalam penelitian ini pencahayaan merupakan faktor resiko yang berhubungan erat dengan kejadian pneumonia.Cahaya mempunyai sifat yang dapat membunuh bakteri. Pencahayaan yang kurang akan menyebabkan kelembaban yang tinggi di dalam rumah dan sangat berpotensi bagi berkembang biaknya bakteri Sterptococcus pneumonia.

Tabel 2. Distribusi Frekuensi Responden Menurut Suhu Rumah Dengan Kejadian Pneumonia Pada Balita

\begin{tabular}{|c|c|c|c|c|c|c|}
\hline \multirow{3}{*}{ No } & \multirow{3}{*}{ Suhu } & \multicolumn{4}{|c|}{ Kejadian Pneumonia } & \multirow{2}{*}{ Jumlah } \\
\hline & & \multicolumn{2}{|c|}{ Kasus } & \multicolumn{2}{|c|}{ Kontrol } & \\
\hline & & $\mathrm{n}$ & $\%$ & $\mathrm{n}$ & $\%$ & \\
\hline 1. & Tidak memenuhi syarat & 18 & 72 & 13 & 52 & 31 \\
\hline \multirow[t]{2}{*}{2.} & Memenuhi syarat & 7 & 28 & 12 & 48 & 19 \\
\hline & Total & 25 & 100 & 25 & 10 & 50 \\
\hline & & & & & & \\
\hline & & & & & & \\
\hline
\end{tabular}

Hasil analisis data dengan menggunakan uji chi-square diperoleh nilai $p$-value sebesar $0,244>\alpha(0,05)$ maka $\mathrm{H}_{\mathrm{o}}$ diterima sehingga dapat dikatakan bahwa tidak ada hubungan antara suhu dengan kejadian pneumonia pada balita di Kecamatan Astambul Kabupaten Banjar. Hal yang menyebabkan tidak adanya hubungan antara suhu dengan kejadian pneumonia pada penelitian ini karenatidak ada perbedaan yang signifikan pada suhu rumah pada rumah kelompok kasus maupun kontrol

Tabel 3. Distribusi Frekuensi Responden Menurut Kelembaban Rumah Dengan Kejadian Pneumonia Pada Balita

\begin{tabular}{|c|c|c|c|c|c|c|}
\hline \multirow{3}{*}{ No } & \multirow{3}{*}{ Kelembaban } & \multicolumn{4}{|c|}{ Kejadian Pneumonia } & \multirow{2}{*}{ Jumlah } \\
\hline & & \multicolumn{2}{|c|}{ Kasus } & \multicolumn{2}{|c|}{ Kontrol } & \\
\hline & & $\mathrm{n}$ & $\%$ & $\mathrm{n}$ & $\%$ & \\
\hline 1. & Tidak memenuhi syarat & 4 & 16 & 5 & 20 & 9 \\
\hline 2. & Memenuhi syarat & 21 & 84 & 20 & 80 & 41 \\
\hline & Total & 25 & 100 & 25 & 100 & 50 \\
\hline
\end{tabular}

Hasil analisis data dengan menggunakan uji chi-square diperoleh nilai $p$-value sebesar $0,244>\alpha(0,05)$ maka $\mathrm{H}_{0}$ diterima sehingga dapat dikatakan bahwa tidak ada hubungan antara suhu dengan kejadian pneumonia pada balita di Kecamatan Astambul Kabupaten Banjar. Hal yang menyebabkan tidak adanya hubungan antara kelembaban dengan kejadian pneumonia pada penelitian ini karena tidak ada perbedaan yang signifikan pada kelembaban rumah pada rumah kelompok kasus maupun kontrol

\section{KESIMPULAN DAN SARAN}

Tidak terbukti secara statistik ada hubungan antara pencahayaan dengan kejadian pneumonia, tidak terbukti secara statistik ada hubungan antara suhu dengan kejadian pneumonia, dan tidak terbukti secara statistik ada hbungan kelembaban dengan kejadian pneumonia pada balita di Kabupaten Banjar. Diharapkan dengan penyuluhan dari Puskesmas Astambul masyarakat mampu meningkatkan pengetahuan dan kesadaran tentang persyaratan rumah sehat serta memperhatikan kesehatan lingkungan rumahnya. 


\section{KEPUSTAKAAN}

1. Soedjajadi. 2005. Kesehatan Perumahan dan Lingkungan Permukiman. Jurnal Kesehatan Lingkungan Vol.2, No.1.

2. Taylor, V., 2002. Health Hardware for Housing for Rural and Remote Indigenous Communities. Australia: Central Australian Division of General Practice.

3. Fahimah R. 2014.Kualitas Udara Ruma Dengan Kejadian Pneumonia Anak Bawah Lima Tahun. Makara J Health Res.
4. Dinas Kesehatan Kabupaten Banjar, (2017). Data Pneumonia Balita Tahun 2013, Kabupaten Banjar : Dinas Kesehatan Kabupaten Banjar.

5. Puskesmas Astambul, (2018). Jumlah Kasus Pneumonia di Wilayah Kerja Puskesmas Astambul Tahun 2018. Kabupaten Banjar : Puskesmas Astambul Kecamatan Astambul 